[Research Paper]

\title{
A Comparison of Methods for Estimating the Productivity of Zostera marina
}

\author{
Sang Rul Park, Wen-Tao Li, Seung Hyeon Kim, Jae Woo Kim, Kun-Seop Lee*
}

Department of Biological Sciences, Pusan National University, Pusan 609-735, Korea

\begin{abstract}
Because seagrass production significantly contributes to the biodiversity and production of coastal and estuarine ecosystems, accurate estimation of seagrass productivity is a critical step toward understanding the ecological roles of seagrass in these ecosystems. To develop an accurate and effective method of measuring seagrass productivity, we estimated leaf productivity of eelgrass (Zostera marina) on the southern coast of Korea using three methods, the conventional leaf marking method, the elongation-mass method (Short ' 87 method), and the plastochrone method. In each season, shoots were pierced through the bundle sheath using a hypodermic needle and were collected after 2-4 weeks had elapsed to estimate their productivity. The leaf elongation and the leaf plastochrone intervals varied significantly among seasons. On an annual basis, the conventional leaf marking method showed the lowest leaf productivity estimates compared to the elongation-mass method and the plastochrone method, suggesting that the conventional leaf marking method underestimated leaf productivity as it ignored leaf maturation processes and new leaf growth within the sheath. Since the elongation-mass method considered leaf maturation processes, this method produced higher leaf productivity estimates than the conventional leaf marking method. On an annual basis, the plastochrone method produced the highest leaf productivity estimates. Below-ground productivity, which can be easily estimated using the plastochrone method, ranged between 3.29 and $5.73\left(\mathrm{mg} \mathrm{dry}\right.$ weight shoot $^{-1}$ day $^{-1}$ ) and accounted for about $17.8 \%$ to $30.3 \%$ of total productivity. Because of the high contributions of below-ground productivity to total seagrass production, we suggest that the plastochrone method is an effective and simple technique for assessing both above- and below-ground productivities.
\end{abstract}

Key words: leaf elongation, leaf plastochrone interval, productivity measurement, seagrass, Zostera marina

\section{INTRODUCTION}

Seagrasses are a specialized group of flowering plants that are believed to have returned to the sea and adapted to living completely underwater (McComb et al. 1981, Robertson 1984). Seagrass meadows are among the most productive plant communities, and they provide habitats and shelter for commercially and ecologically valuable marine organisms (Holmquist et al. 1989, Montague and Ley 1993). Seagrass production significantly contributes to the abundance and production of a wide variety of organisms in coastal and estuarine ecosystems (Heck et al. 1995, Vizzini et al. 2002). Because seagrasses have high productivity, they require high nutrient inputs and play an important role in nutrient cycling in these ecosystems (Blackburn et al. 1994, Park et al. 2009). Thus, accurate assessment of seagrass productivity is critical to understanding the ecological role and value of seagrass beds.

Numerous methods have been developed to measure seagrass productivity (for a review, see Kemp et al. 1990). The leaf marking method developed by Zieman (1974, 1975) has been widely used to assess leaf productivity and was improved by several researchers (Sand-Jensen 1975, Kentula and McIntire 1986, Roman and Able 1988, Dennison 1990a, Ibarra-Obando and Boudouresque 1994). However, this method can produce underestimates

${ }^{\star}$ Corresponding author: Phone: +82-51-510-2255, e-mail: klee@pusan.ac.kr 


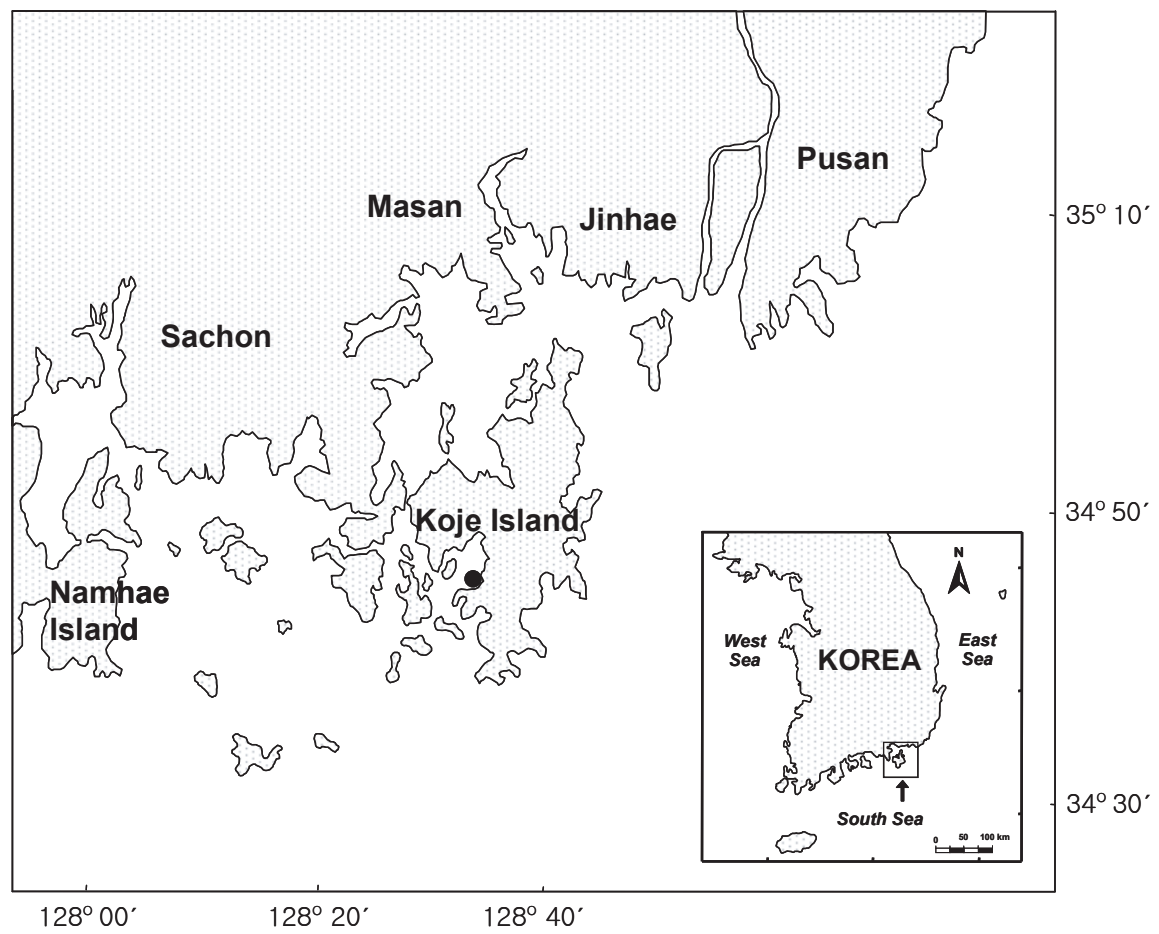

Fig. 1. Study site in Koje Bay on the southern coast of the Korean peninsula.

due to its failure to consider new leaf growth within the sheath below the reference mark (Sand-Jensen 1975, Ibarra-Obando and Boudouresque 1994), damage to the leaf tissues caused by marking (Dennison 1990a), and its disregard for the leaf maturation process (Bédhomme et al. 1983. Short 1987, Gaeckle and Short 2002). Thus, a new productivity assessment method, the elongationmass method (Short ' 87 method), in which both leaf elongation and weight gain are considered, has been developed to reduce the downward bias in seagrass leaf productivity resulting from weighing immature leaf sections from newly grown leaf tissues (Short 1987, Gaeckle and Short 2002). In this method, leaf productivity is calculated by multiplying the leaf elongation rate by the leaf weight-to-length ratio $\left(\mathrm{mg} \mathrm{cm}^{-1}\right)$ of mature leaf material to account for the leaf weight gain that is part of the total leaf growth; thus, this method can reflect leaf maturation processes (Gaeckle and Short 2002).

The plastochrone method was developed to complement previous ways of measuring seagrass productivity (Short and Duarte 2001). The leaf plastochrone interval is defined as the period between successive initiations of two leaves on a shoot (Patriquin 1973, Sand-Jensen 1975, Jacobs 1979). In the plastochrone method, leaf productivity is calculated based on the plastochrone interval and the weight of a mature leaf. This method was described as a simple and accurate technique for assessment of seagrass productivity (Short and Duarte 2001, Gaeckle and Short 2002, Lee 2004). Although seagrass productivity has been measured using these methods worldwide, few studies have compared these three measuring methods. In the present study, we compared three measurement methods, the commonly used leaf marking method, the elongation-mass method, and the plastochrone method, to determine which is the more accurate and reliable technique for measuring seagrass productivity.

\section{MATERIALS AND METHODS}

\section{Study area}

Our study was conducted in Koje Bay (N 34 $48^{\circ}$, E $\left.128^{\circ} 35^{\prime}\right)$ on the southern coast of the Korean peninsula (Fig. 1). Four Zostera species (Z. japonica, Z. marina, Z. caespitosa, and $Z$. caulescens) are distributed at different water depths in this area. Since $Z$. marina occupies the intertidal and subtidal zones and exhibits morphological differences between the two zones, we conducted this study only in subtidal $Z$. marina meadows at an average water depth of $\sim 1 \mathrm{~m}$ relative to the mean sea level. The study site was characterized by a high sand content in the sediment. The tidal regime is semi-diurnal and the 
system is classified as mesotidal, with a maximum tidal range of about $2.5 \mathrm{~m}$ during spring tides (Tide Tables for the Coast of Korea, National Oceanographic Research Institute of Korea). Mean water temperatures in October 2004 and January, March and June 2005 were $20.5^{\circ} \mathrm{C}$, $8.3^{\circ} \mathrm{C}, 12.0^{\circ} \mathrm{C}$, and $24.0^{\circ} \mathrm{C}$, respectively.

\section{Leaf marking and leaf productivity estimates}

We estimated leaf elongation, leaf plastochrone interval and leaf productivity in each season (October 2004 and January, March and June 2005). Thirty to forty shoots of $Z$. marina were pierced through the bundle sheath using a hypodermic needle, and then tied with plastic string to facilitate later identification of the marked shoots. After 2-4 weeks had elapsed, the marked shoots were harvested and rinsed in fresh water.

For the conventional leaf marking method, leaf material was separated into leaf tissue produced before and after marking. Any epiphytes and sediments were removed from these leaves by gentle scraping. Separated leaf materials were dried at $60^{\circ} \mathrm{C}$ to a constant weight. Leaf productivity (mg dry weight shoot ${ }^{-1}$ day $^{-1}$ ) was estimated using the conventional leaf marking method by dividing the dry weight of new leaf tissue produced after marking by the number of days since marking.

For the elongation-mass method, the total length of new leaf tissues produced after marking was measured. Additionally, a weight-to-length ratio $\left(\mathrm{mg} \mathrm{cm}^{-1}\right)$ was measured using 20-30 $\mathrm{cm}$ of mature leaf material (generally the third leaf). The mature leaf material was cleaned of epiphytes and dried at $60^{\circ} \mathrm{C}$ to a constant weight; then the weight-to-length ratio was calculated. Leaf productivity was estimated using the elongationmass method by multiplying the weight-to-length ratio by the length of new leaf material produced after marking.

For the plastochrone method, the leaf plastochrone interval was calculated by dividing the marking period by the number of new leaves produced after marking. The dry weights of the youngest mature leaf and the rhizome/ root segments from the first to sixth youngest nodes were measured at every sampling interval. The youngest mature leaf was generally the third leaf and the youngest mature rhizome segment was usually the longest one. Leaf and below-ground productivities of each shoot were calculated using the following equations:

Leaf productivity (mg dry weight shoot ${ }^{-1}$ day $\left.^{-1}\right)=$ dry weight of the youngest mature leaf (mg dry weight shoot $^{-1}$ ) / the plastochrone interval (days)

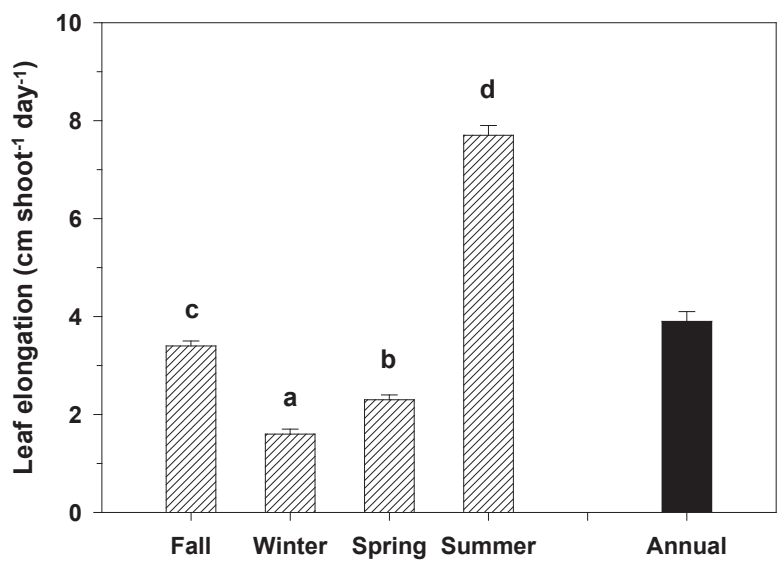

Fig. 2. Seasonal and annual estimate of Zostera marina leaf elongation $\left(\mathrm{cm} \mathrm{shoot}^{-1}\right.$ day $\left.^{-1}\right)$ in Koje Bay. Values with the same letter are not significantly different among seasons. Values are means \pm SE $(n=30-35)$.

Below-ground productivity (mg dry weight shoot ${ }^{-1}$ day $\left.^{-1}\right)=$ dry weight of a mature rhizome/root segment $\left(\mathrm{mg}\right.$ dry weight shoot $\left.^{-1}\right) /$ the plastochrone interval (days)

\section{Statistical analysis}

All data are presented as means \pm SE. Data were tested for homogeneity and normality of variances to meet the assumptions of parametric statistics. If these assumptions were violated, data were log-transformed. We assessed the significance of the differences in leaf elongation and leaf plastochrone interval among seasons using one-way ANOVA. We also tested for significant differences in leaf productivity estimates using the three measurement methods in each season and compared total, aboveground and below-ground productivities among seasons with one-way ANOVA. When a significant difference among the variables was observed, the means were compared using the Student-Newman-Keuls test to determine which of the treatments differed significantly. We also compared the slopes of the linear regressions between leaf productivity estimates using the three measurement methods. An alpha level of 0.05 was used for statistical tests. All data analyses were performed using SPSS (version 12.0).

\section{RESULTS}

\section{Leaf elongation and leaf plastochrone interval}

Leaf elongation exhibited significant $(\mathrm{P}<0.001)$ seasonal variation (Fig. 2). The rate of leaf elongation ranged from $1.6 \mathrm{~cm} \mathrm{shoot}^{-1}$ day $^{-1}$ in January 2005 to 7.8 


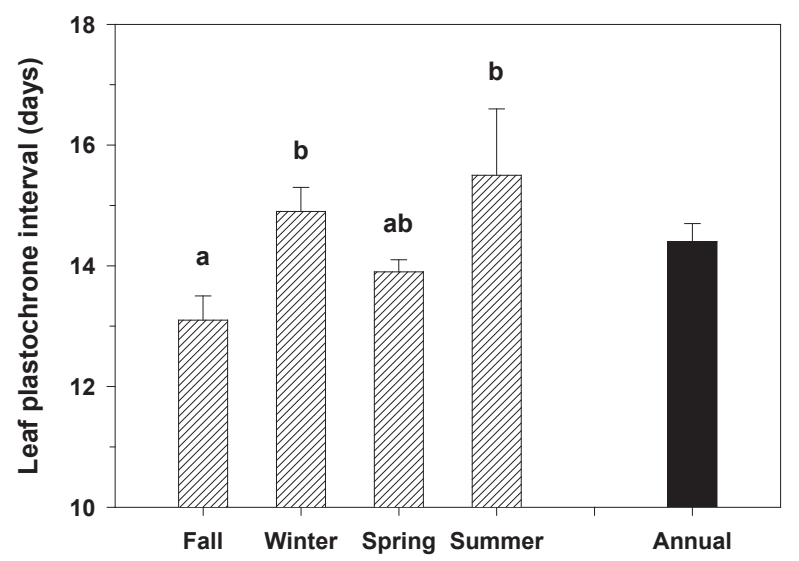

Fig. 3. Seasonal and annual estimate of Zostera marina leaf plastochrone intervals (days) in Koje Bay. Values with the same letter are not significantly different among seasons. Values are means \pm SE $(n=30-35)$.

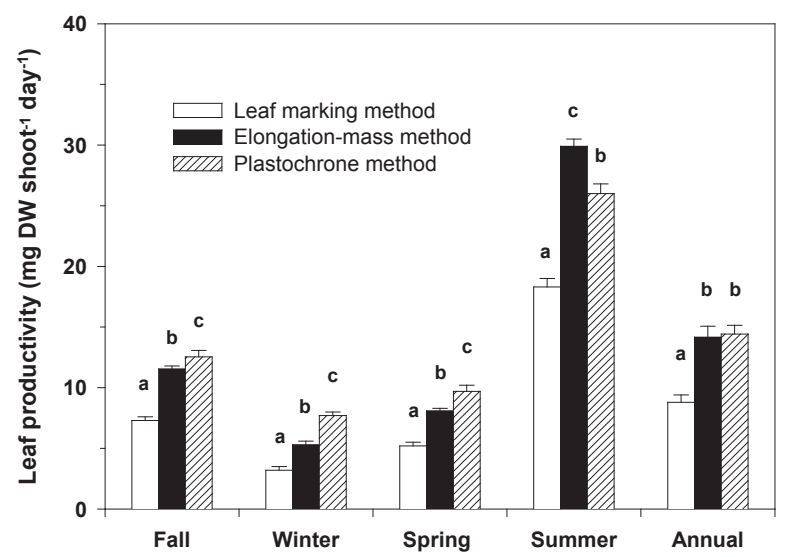

Fig. 4. Zostera marina leaf productivities (mg dry weight shoot $^{-1}$ day $^{-1}$ ) estimated using three measurement methods (the conventional leaf marking method, the elongation-mass method and the plastochrone method) in each season in Koje Bay. Values with the same letter are not significantly different among the measurement methods in each season. Values are means \pm SE $(n=$ 30-35).

$\mathrm{cm}$ shoot $^{-1}$ day $^{-1}$ in June 2005; the annual mean was $3.9 \pm$ $0.2 \mathrm{~cm} \mathrm{shoot}^{-1}$ day $^{-1}$. The leaf plastochrone interval also varied significantly $(\mathrm{P}=0.045)$ among seasons. The leaf plastochrone interval was highest (15.5 \pm 1.6 days) in summer and lowest (13.1 \pm 0.4 days) in fall (Fig. 3). The annual mean leaf plastochrone interval was 14.4 days.

\section{Comparisons of the three measurement methods}

Leaf productivity estimates produced with the three measurement methods (the conventional leaf marking method, the elongation-mass method and the
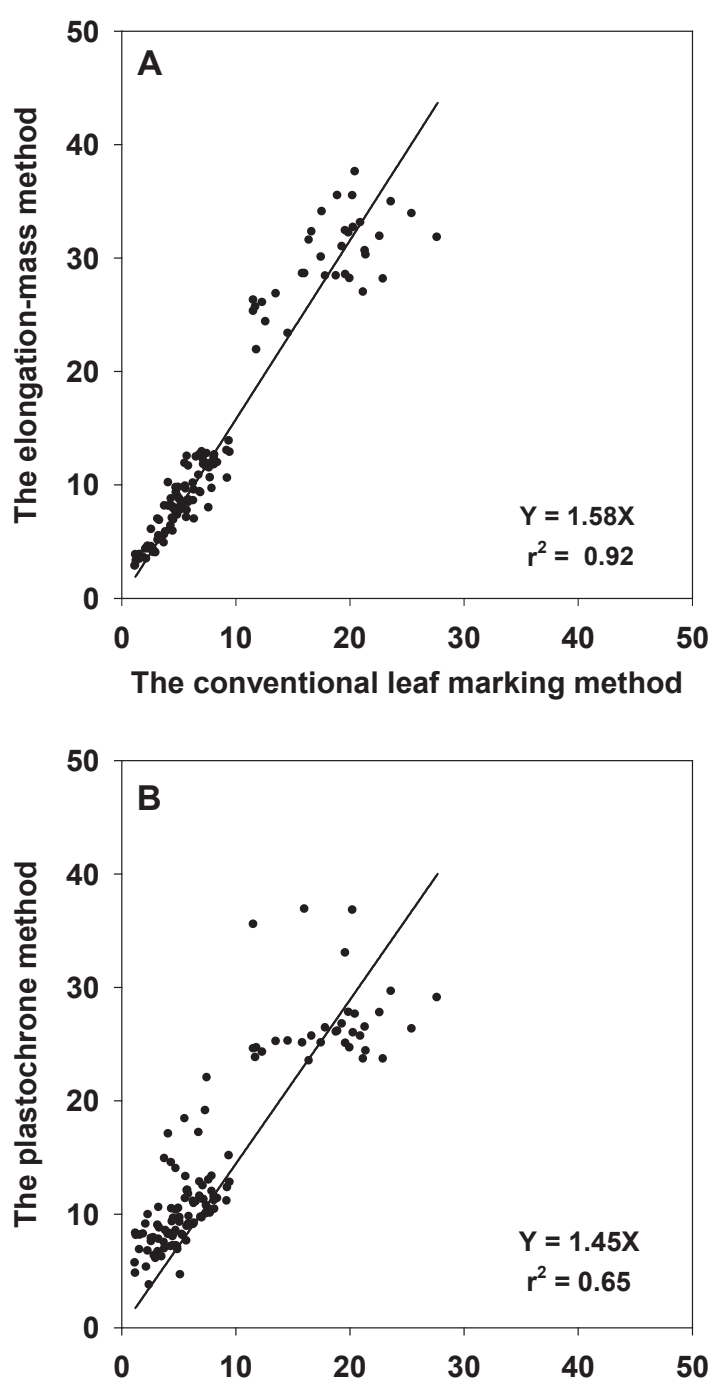

The conventional leaf marking method

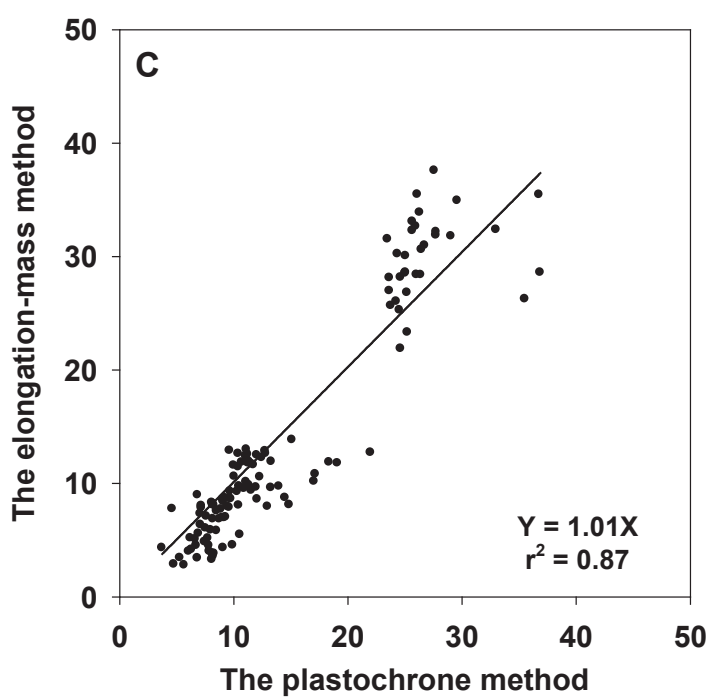

Fig. 5. The relationships between leaf productivities (mg dry weight shoot $^{-1}$ day $^{-1}$ ) estimated using the three measuring methods. 
Table 1. Above-ground, below-ground, and total shoot productivities ( $\mathrm{mg}$ dry weight shoot ${ }^{-1} \mathrm{~d}^{-1}$ ) of Zostera marina estimated using the plastochrone method.

\begin{tabular}{lccc}
\hline & \multicolumn{2}{c}{ Eelgrass productivity (\% of total productivity) } \\
\cline { 2 - 4 } & Above-ground & Below-ground & Total productivity \\
\hline Fall & $12.54 \pm 0.53^{\mathrm{c}}(76.5)$ & $3.86 \pm 0.20^{\mathrm{a}}(23.5)$ & $16.40 \pm 0.69^{\mathrm{c}}(100.0)$ \\
Winter & $7.66 \pm 0.30^{\mathrm{a}}(70.0)$ & $3.29 \pm 0.14^{\mathrm{a}}(30.0)$ & $10.96 \pm 0.43^{\mathrm{a}}(100.0)$ \\
Spring & $9.71 \pm 0.51^{\mathrm{b}}(72.5)$ & $3.67 \pm 0.20^{\mathrm{a}}(27.5)$ & $13.38 \pm 0.70^{\mathrm{b}}(100.0)$ \\
Summer & $26.0 \pm 0.82^{\mathrm{d}}(82.2)$ & $5.73 \pm 0.32^{\mathrm{b}}(17.8)$ & $31.76 \pm 1.05^{\mathrm{d}}(100.0)$ \\
Annual mean & $14.42 \pm 0.72(75.6)$ & $4.19 \pm 0.14(24.4)$ & $18.61 \pm 0.84(100.0)$ \\
\hline
\end{tabular}

Values with the same letter are not significantly different among seasons.

plastochrone method) differed significantly throughout the experimental periods (Fig. 4). Leaf productivities estimated using the plastochrone method were significantly higher $(\mathrm{P}<0.001)$ than those estimated using the conventional leaf marking method and the elongation-mass method in all experimental seasons except summer (Fig. 4). During fall, winter, and spring, the values derived using the plastochrone method were 1.7-2.4 times higher than those produced using the conventional leaf marking method and 1.1-1.6 times higher than those derived using the elongation-mass method.

Leaf productivity estimates produced using the elongation-mass method were significantly higher $(\mathrm{P}<$ 0.001) than those estimated using the conventional leaf marking method throughout the experimental periods and were also higher than the plastochrone-methodbased estimates in summer, when leaf elongation was highest (Fig. 4). The conventional leaf marking method consistently produced the lowest leaf productivity estimates. On an annual basis, leaf productivity estimates produced with the conventional leaf marking method were $38 \%$ and $39 \%$ lower than those produdced with the elongation-mass method and the plastochrone method, respectively (Fig. 4).

Estimates of leaf productivity using the three measurement methods were strongly correlated (Fig. 5). Estimates produced using the conventional leaf marking method exhibited the strongest relationship with those from the elongation-mass method $\left(r^{2}=0.92\right)$ and a weaker relationship with those using the plastochrone method $\left(\mathrm{r}^{2}=0.65\right)$. Estimates produced using the elongation-mass method also showed a high and significant correlation $\left(r^{2}=0.87\right)$ with those produced using the plastochrone method.

\section{Below-ground productivity using the plastochrone method}

Below-ground productivity was relatively constant during all seasons except summer (Table 1). Belowground productivity was highest in summer $(5.73 \mathrm{mg}$ dry weight shoot $^{-1}$ day $\left.^{-1}\right)$ and lowest in winter $(3.29 \mathrm{mg}$ dry weight shoot ${ }^{-1}$ day $\left.^{-1}\right)$. Below-ground production accounted for $24.4 \%$ of total production on an annual basis. Total (above- + below-ground) productivity varied significantly $(\mathrm{p}<0.001)$ with season (Table 1$)$. Total productivity was highest in summer (31.76 mg dry weight shoot $^{-1}$ day $^{-1}$ ) and lowest in winter (10.96 mg dry weight shoot $^{-1}$ day $^{-1}$ ).

\section{DISCUSSION}

The leaf marking technique described by Zieman $(1974,1975)$ has been the predominant method used to assess the leaf productivity of seagrasses over the past 30 years. However, several researchers have pointed out inherent problems with the conventional leaf marking method (Sand-Jensen 1975, Brouns 1985, Ibarra-Obando and Boudouresque 1994, Gaeckle and Short 2002). The leaf marking method ignores maturation of leaf tissues located above the marking point (Bédhomme et al. 1983, Short 1987, Gaeckle and Short 2002), and new leaf growth occurring below the marking point may also be excluded in the conventional leaf marking method (Sand-Jensen 1975, Brouns 1985, Ibarra-Obando and Boudouresque 1994). In this study, the conventional leaf marking method resulted in the lowest leaf productivity values among the three measurement techniques. On an annual basis, leaf productivities estimated by the conventional leaf marking method were only $62 \%$ and $61 \%$ of those estimated using the elongation-mass and the plastochrone methods, respectively. Regressions among estimates produced using the three measurement methods also showed that the conventional leaf marking method produced the lowest estimates of leaf productivity. Thus, as many researchers have pointed out, productivity estimates produced using the conventional leaf marking method probably underestimate actual 
productivity due to the failure to include leaf maturation processes and new leaf growth within the sheath.

Since the elongation-mass method incorporates leaf maturation processes, this technique is considered to be a more complete productivity measurement modality than the conventional leaf marking method (Gaeckle and Short 2002). Although the elongation-mass method can reflect leaf tissue maturation processes, this method still ignores new leaf growth below the marking points. On an annual basis, leaf productivity estimates using the elongation-mass method were approximately $98 \%$ of those attained with the plastochrone method. However, the elongation-mass method estimated 15\% higher leaf productivity than the plastochrone method during summer, when leaf elongation rates increased dramatically.

Leaf productivity usually exhibits clear seasonal variation, increasing during spring and early summer, and decreasing during fall and winter (Lee et al. 2005). During summer, leaf maturation processes appeared to be at a minimum as leaves elongated greatly (Park 2008). Since completely mature leaf tissues were used to calculate leaf productivity with the elongation-mass method, the productivity estimate produced using this technique may be an overestimate during seasons of maximum leaf elongation. Gaeckle and Short (2002) also reported that productivity estimations generated using the elongationmass method were higher than those made using the plastochrone method in July.

Of the three measurement methods, the plastochrone method generated the highest leaf productivity estimates on an annual basis. The leaf productivity estimates made with the plastochrone method were $64 \%$ and $2 \%$ higher than those obtained with the conventional leaf marking method and the elongation-mass method, respectively. Leaf productivities estimated using the plastochrone method reflect both leaf maturation and growth within the sheath. Assessment of belowground productivity is remarkably difficult (Dennison 1990b). Rhizome tagging has been used to estimate below-ground productivity (Dennison et al. 1985), but tagging rhizomes requires substantial effort under field conditions. Below-ground production has been assessed as $15-43 \%$ of the total seagrass production (Nienhuis and de Bree 1980, Robertson and Mann 1984, Park et al. 2009). We estimated below-ground productivities using the plastochrone method as $3.29-5.73 \mathrm{mg}$ dry weight shoot $^{-1}$ day $^{-1}$, which accounted for about $18-30 \%$ (mean $=24 \%$ ) of total eelgrass productivity. In Koje Bay, leaf biomass ranged from $12 \mathrm{~g}$ dry weight $\mathrm{m}^{-2}$ in December to $696 \mathrm{~g}$ dry weight $\mathrm{m}^{-2}$ in June, whereas below-ground biomass ranged from $7 \mathrm{~g}$ dry weight $\mathrm{m}^{-2}$ in March to $92 \mathrm{~g}$ dry weight $\mathrm{m}^{-2}$ in August (Lee et al. 2005). Below-ground biomass accounted for about $20 \%$ of the total biomass. Thus, below-ground productivity in this study was consistent with the pattern of biomass allocation. These high contributions of below-ground productivity to total seagrass production imply that below-ground production should not be ignored when attempting to clarify seagrass production dynamics. Below-ground productivity as well as above-ground productivity can be easily estimated using the plastochrone method. Thus, the plastochrone method is an effective assessment modality for total seagrass productivity.

In conclusion, the results of our comparisons of the three measurement methods suggest that the conventional leaf marking method underestimates eelgrass leaf productivity as it ignores leaf maturation processes and new leaf growth within the sheath. Since the elongation-mass method can reflect leaf maturation processes, it appeared to provide a more reliable leaf productivity estimate than the conventional leaf marking method. However, the plastochrone method appears to be the most effective assessment technique for measuring both above- and below-ground productivities.

\section{ACKNOWLEDGMENTS}

We thank YK Kim, JH Kim, and YW Lee for their countless hours of field and lab assistance. Anonymous reviewers provided helpful comments on the earlier version of this manuscript. This work was supported by the Korean Research Foundation Grant funded by the Korean government (KRF-2008-314-C00318) and the Korean Sea Grant Program.

\section{LITERATURE CITED}

Bédhomme AL, Thélin I, Boudouresque CF. 1983. Mesure de la production primaire des feuilles de Posidonia oceanica: Modifications de la méthode de Zieman. Bot Mar 26: 3543.

Blackburn TH, Nedwell DB, Weibe WJ. 1994. Active mineral cycling in a Jamaican seagrass sediment. Mar Ecol Prog Ser 110: 233-239.

Brouns JJWM. 1985. The plastochrone interval method for the study of the productivity of seagrasses: Possibilities and limitations. Aquat Bot 21: 71-88.

Dennison WC. 1990a. Leaf production. In RC Phillips, CP McRoy, eds, Seagrass Research Methods, Monographs on Oceanographic Methodology, 9, UNESCO, Paris, pp 77- 
79.

Dennison WC. 1990b. Rhizome/root production. In Seagrass Research Methods (Phillips RC, McRoy CP, eds). Monographs on Oceanographic Methodology, 9, UNESCO, Paris, pp 81-82.

Dennison WC, Aller RC, Alberte RS. 1985. Sediment ammonium availability and eelgrass (Zostera marina) growth. Mar Biol 94: 469-477.

Gaeckle JL, Short FT. 2002. A plastochrone method for measuring leaf growth in eelgrass, Zostera marina L. Bull Mar Sci 71: 1237-1246.

Heck Jr KL, Able KW, Roman CT, Fahay MP. 1995. Composition, abundance, biomass, and production of macrofauna in a New England estuary - comparisons among eelgrass meadows and other nursery habitats. Estuaries 18: 379-389.

Holmquist JG, Powell GVN, Sogard SM. 1989. Decapod and stomatopod assemblages on a system of seagrass-covered mud banks in Florida Bay. Mar Biol 100: 473-483.

Ibarra-Obando SE, Boudouresque CF. 1994. An improvement of the Zieman leaf marking technique for Zostera marina growth and production assessment. Aquat Bot 47: 293302.

Jacobs RPWM. 1979. Distribution and aspects of the production and biomass of eelgrass Zostera marina L., at Roscoff, France. Aquat Bot 7: 151-172.

Kemp M, Murray L, McRoy CP. 1990. Primary productivity. In Seagrass Research Methods (Phillips RC, McRoy CP, eds). Monographs on Oceanographic Methodology, 9, UNESCO, Paris, pp. 153-159.

Kentula ME, McIntire CD. 1986. The autecology and production dynamics of eelgrass (Zostera marina L.) in Netarts Bay, Oregon. Estuaries 9: 188-199.

Lee K-S. 2004. Production assessment of eelgrass, Zostera marina using the plastochrone method compared with the conventional leaf marking technique. J Korean Soc Oceanogr 39: 186-196.

Lee K-S, Park SR, Kim J-B. 2005. Production dynamics of the eelgrass, Zostera marina in two bay systems on the south coast of the Korean peninsula. Mar Biol 147: 1091-1108.

McComb AJ, Cambridge ML, Kirkman H, Kuo J. 1981. The biology of Australian seagrass. In The Biology of Australian Plants (Pate JS, McComb AJ, eds) University of Western Australia Press, pp 258-293.

Montague CL, Ley JA. 1993. A possible effect of salinity fluctuation on abundance of benthic vegetation and associated fauna in northeastern Florida Bay. Estuaries 16: 703-717.
Nienhuis PH, de Bree BHH. 1980. Production and growth dynamics of eelgrass (Zostera marina) in brackish Lake Grevelingen (The Netherlands). Netherlands J Sea Res 14: 102-118.

Park SR. 2008. Production dynamics of three Zostera species on the southern coast of the Korean peninsula. Ph.D. thesis. Pusan National University, Pusan

Park SR, Kim J-H, Kang C-K, An S, Chung IK, Kim JH, Lee K-S. 2009. Current status and ecological roles of Zostera marina after recovery from large-scale reclamation in the Nakdong River estuary, Korea. Estuar Coast Shelf Sci 81: 38-48.

Patriquin D. 1973. Estimation of growth rate, production and age of the marine angiosperm Thalassia testudinum König. Carb J Sci 13: 1-2.

Robertson AI, Mann KH. 1984. Disturbance by ice and lifehistory adaptations of the seagrass Zostera marina. Mar Biol 80: 131-141.

Robertson EL. 1984. Seagrasses. In The Marine Benthic Flora of Southern Australia Plant 1. South Australia (HBS Womersley, ed). Government Printer, pp 57-122.

Roman CT, Able KW. 1988. Production ecology of eelgrass (Zostera marina L.) in a Cape Cod salt marsh-estuarine system, Massachusetts. Aquat Bot 32: 353-363.

Sand-Jensen K. 1975. Biomass, net production and growth dynamics in an eelgrass (Zostera marina L.) population in Vellerup Vig, Denmark. Ophelia 14: 185-201.

Short FT. 1987. Effects of sediment nutrients on seagrasses: Literature review and mesocosm experiment. Aquat Bot 27: 41-57.

Short FT, Duarte CM. 2001. Methods for the measurement of seagrass growth and production. In Global Seagrass Research Methods (Short FT, Coles RG, eds). Elsevier, Amsterdam, pp 154-182.

Vizzini S, Sarà G, Michener RH, Mazzola A. 2002. The role and contribution of the seagrass Posidonia oceanica (L.) Delile organic matter for secondary consumers as revealed by carbon and nitrogen stable isotope analysis. Acta Oecol 23: 277-285.

Zieman JC. 1974. Methods for the study of the growth and production of turtle grass, Thalassia testudinum König. Aquaculture 4 139-143.

Zieman JC. 1975. Quantitative and dynamic aspects of the ecology of turtle grass, Thalassia testudinum. In Estuarine Research, Vol. 1 (Cronin LE, ed). Academic Press, New York, pp 541-562.

(Received January 19, 2010; Accepted February 6, 2010) 